\title{
An editorial commentary on non-in situ technique of heart-lung transplantation: could this 'not-in-place' method get in place?
}

\author{
Min $\mathrm{Ho} \mathrm{Ju}^{1} \wedge$, Soo Yong $\mathrm{Lee}^{2 \wedge}$ \\ ${ }^{1}$ Department of cardiovascular surgery and Research Institute for Convergence of Biomedical Science and Technology, Pusan National University \\ Yangsan Hospital, Yangsan, Republic of Korea; ${ }^{2}$ Division of Cardiology, Department of Internal Medicine and Research Institute for Convergence of \\ Biomedical Science and Technology, Pusan National University Yangsan Hospital, Pusan National University School of Medicine, Yangsan, Republic \\ of Korea \\ Correspondence to: Soo Yong Lee, MD, PhD. Division of Cardiology, Department of Internal Medicine, Pusan National University School of \\ Medicine, Pusan National University Yangsan Hospital, Geum-o Street 20, Yangsan 626-770, Republic of Korea. Email: shonge0906@gmail.com. \\ Comment on: Xu X, Shi J, Peng G, et al. Non-In Situ Technique of Heart-Lung Transplantation: Case Series and Technique Description. Ann Thorac \\ Surg 2021;112:661-4.
}

Submitted Aug 27, 2021. Accepted for publication Sep 13, 2021.

doi: $10.21037 /$ jtd-21-1419

View this article at: https://dx.doi.org/10.21037/jtd-21-1419

Heart-lung transplantation (HLTx) is an effective treatment for advanced cardiopulmonary failure. The one-year posttransplant survival has improved over time. However, it was reportedly less than $75 \%$, and the mortality rate is high early after transplantation. Intraoperative technical complications, such as massive bleeding, are the major cause of 30-day mortality in HLTx (1). Thus, establishing novel methods that lower mortality from technical issues is essential.

Conventional HLTx involves making a pericardial phrenic pedicle, followed by remnant recipient tissue removal with posterior mediastinal dissection. It has been performed during pneumo-cardiectomy to obtain adequate space for implanted heart-lung block (2). Prolonged cardiopulmonary bypass time, extensive mediastinal dissection, and visual acuity disturbances during bleeding control in the posterior mediastinum cause massive bleeding (3). Thus, massive transfusion and another session of bleeding control surgery are necessary. Additionally, the complications compound on one another. The phrenic nerve may be damaged during the formation of pericardial phrenic pedicles, prolonging ventilator care and intensive care unit (ICU) stay (4).

An article by $\mathrm{Xu}$ et al. introduced an innovative HLTx technique named "non-in situ technique". It was applied in three cases to reduce complications (5). The authors compared the three "non-in situ" cases with 12 conventional cases, treated surgically between 2015 and 2019. The non-in situ technique involved leaving the recipient organ residue [posterior left atrial (LA) wall, trachea, and bronchi below the transected margin], that were strongly attached to the posterior mediastinum during pneumo-cardiectomy. The donor heart and lungs were placed anterior to the native LA and pulmonary hila and oversewn. In this method, the phrenic nerves remained intact behind the donor organs. The implanted organs were superimposed on the native organs, such that they are not in situ. Alternatively, this technique has been described as the "minimal manipulation technique of the posterior mediastinum". The patient, who underwent HLTx with the "non-in situ technique", had a reduced total surgical time, cold ischemic time, intraoperative bleeding, intraoperative transfusion, ICU and hospital stay. However, we could hardly say it was statistically significant for the extremely small sample size. The authors concluded that "non-in situ HLTx" reduced posterior mediastinal bleeding and phrenic nerve damage, leading to rapid postoperative recovery.

This "modified technique" is not entirely novel in fact.

^ ORCID: Min Ho Ju, 0000-0001-7839-8598; Soo Yong Lee, 0000-0003-2616-1294. 
Cabrol et al. suggested leaving the recipient pulmonary artery, carina and the back walls of the main bronchi intact for lesser posterior mediastinal dissection in 1984 (6). In 1995, the intraoperative technical complications in HLTx were reportedly high at 59\%, and Lick et al. refined Cabrol's technique $(7,8)$. The recipient trachea was transected one ring above the carina, and the distal bronchi were left in situ. To prevent later-onset mucocele, the mucosa of the recipient distal bronchi was obliterated using an argon beam coagulator. Phrenic nerve pedicles were not constructed, and the hila of the implanted graft was placed in front of the phrenic nerve to minimize posterior mediastinal wall dissection. The technique was similar to the "in-situ technique", except remnant bronchial mucosa coagulation. It was performed in 10 patients, including two who underwent bleeding control. None experienced other iatrogenic complications, including phrenic nerve injury. In the same year, Icenogle et al. also reported a simplified method, wherein the hila of the heart-lung was positioned in front of the phrenic nerves (9).

These technical trials documented clear benefits. However, there are some potential concerns with these surgical modifications. First, cases involving an oversized donor may experience a shortage of space for the graft in the remnant posterior mediastinal tissue. Second, native phrenic nerve injury is still possible due to the pressure of the graft in front and stretching. Conversely, the graft may also be affected by returning pulmonary venous blood flow from the remnant pericardium or residual native hila. Third, in the "non-in situ" technique, mucocele formation and infection may occur in the oversewn distal bronchi. In cases of preoperative airway infection or pneumonia, the mucocele can develop into an abscess, which poses a significant risk for immunosuppressed patients. The residual mucosa ablation could be-considered to reduce these expected complications as reported previously (7). Nevertheless, past studies did not report any lifethreatening complications in these modified techniques.

HLTx is still a difficult and a complicated surgery that needs a lot of improvement to achieve better outcomes. It is imperative to reduce excessive bleeding and early complications, especially in fatal cases. This detailed modification to improve surgery is worthy and will be a foundation for better outcomes. Further studies with a larger sample size are warranted to obtain stronger evidence of advantages of this technique.

\section{Acknowledgments}

Funding: None.

\section{Footnote}

Provenance and Peer Review: This article was commissioned by the editorial office, Fournal of Thoracic Disease. The article did not undergo external peer review.

Conflicts of Interest: Both authors have completed the ICMJE uniform disclosure form (available at https://dx.doi. org/10.21037/jtd-21-1419). The authors have no conflicts of interest to declare.

Ethical Statement: The authors are accountable for all aspects of the work in ensuring that questions related to the accuracy or integrity of any part of the work are appropriately investigated and resolved.

Open Access Statement: This is an Open Access article distributed in accordance with the Creative Commons Attribution-NonCommercial-NoDerivs 4.0 International License (CC BY-NC-ND 4.0), which permits the noncommercial replication and distribution of the article with the strict proviso that no changes or edits are made and the original work is properly cited (including links to both the formal publication through the relevant DOI and the license). See: https://creativecommons.org/licenses/by-nc-nd/4.0/.

\section{References}

1. Chambers DC, Cherikh WS, Harhay MO, et al. The International Thoracic Organ Transplant Registry of the International Society for Heart and Lung Transplantation: Thirty-sixth adult lung and heart-lung transplantation Report-2019; Focus theme: Donor and recipient size match. J Heart Lung Transplant 2019;38:1042-55.

2. Jamieson SW, Stinson EB, Oyer PE, et al. Operative technique for heart-lung transplantation. J Thorac Cardiovasc Surg 1984;87:930-5.

3. Baldwin JC. Technique of combined heart-lung transplantation. J Card Surg 1992;7:313-23.

4. Ferdinande P, Bruyninckx F, Van Raemdonck D, et al. Phrenic nerve dysfunction after heart-lung and lung transplantation. J Heart Lung Transplant 2004;23:105-9. 
5. Xu X, Shi J, Peng G, et al. Non-In Situ Technique of Heart-Lung Transplantation: Case Series and Technique Description. Ann Thorac Surg 2021;112:661-4.

6. Cabrol C, Gandjbakhch I, Pavie A, et al. Heart and heartlung transplantation: technique and safeguards. J Heart Transplant 1984;3:110-4.

7. Lick SD, Copeland JG, Rosado LJ, et al. Simplified technique of heart-lung transplantation. Ann Thorac Surg

Cite this article as: Ju MH, Lee SY. An editorial commentary on non-in situ technique of heart-lung transplantation: could this 'not-in-place' method get in place? J Thorac Dis 2021;13(10):5576-5578. doi: 10.21037/jtd-21-1419
1995;59:1592-3.

8. Kriett JM, Kaye MP. The Registry of the International Society for Heart and Lung Transplantation: eighth official report--1991. J Heart Lung Transplant 1991;10:491-8.

9. Icenogle TB, Copeland JG. A technique to simplify and improve exposure in heart-lung transplantation. J Thorac Cardiovasc Surg 1995;110:1590-3. 